\title{
Peningkatan Hasil Belajar Siswa melalui Pendekatan MATEMATIKA REALISTIK PADA BILANGAN PECAHAN
}

\author{
Budianto \\ SD Negeri Cipedak 06 Pagi Kecamatan Jagakarsa Jakarta Selatan \\ Jl. RM. Kahfi I Gg Swadaya, Cipedak, Kec. Jagakarsa, Jakarta Selatan, D.K.I. Jakarta, Indonesia \\ budianto9981@gmail.com
}

Artikel diterima: 5 Agustus 2018, direvisi: 21 September 2018, diterbitkan: 30 September 2018

\begin{abstract}
Abstrak
Penelitian ini dilatarbelakangi oleh rendahnya proses pembelajaran dan perolehan hasil belajar yang tidak seimbang antara aspek kognitif, afektif dan psikomotor di SD Negeri Cipedak 06 Pagi Kecamatan Jagakarsa Jakarta Selatan. Subjek penelitian dilakukan di kelas V SD dengan jumlah siswa 32. Perbaikan di titik beratkan pada pemilihan model pembelajaran, agar model yang dipilih lebih mengutamakan keterlibatan siswa secara efektif di dalam memahami dan menerapkan konsep yang dipelajarinya, model yang dimaksud adalah model penerapan matematika realistik. Metode penelitian yang digunakan adalah Penelitian Tindakan Kelas. Subjek penelitian ini adalah SD Negeri Cipedak 06 Pagi Kecamatan Jagakarsa Jakarta Selatan; dilaksanakan 2 siklus 4 pertemuan pada semester genap tahun ajaran 2017/2018. Aktivitas di luar jam pelajaran dari siklus I sampai siklus II semakin berkurang dan pembelajaran semakin efektif dan tentunya menyenangkan. Pada siklus I berhasil dengan baik ditandai dengan adanya peningkatan hasil tes dari hasil pre-test meningkat dalam post-test pada tindakan pertama dari $43,75 \%$ menjadi $71,88 \%$ terjadi peningkatan sebanyak $28,13 \%$ dengan rata-rata sebesar 67,81 . Sedangkan dalam tindakan kedua hasil Pre-Test dan Post-Test adalah $68,75 \%$ menjadi $75 \%$ dengan rata-rata 69,97 . Hasil dari Siklus II tindakan pertama dalam pre-test dan post-test adalah dari $75 \%$ menjadi $81,75 \%$ dengan rata-rata 73,06 . Hasil pre-test dan Post-test dari tindakan kedua adalah $84,38 \%$ menjadi $93,75 \%$ dengan rata-rata 77,94 .

Kata Kunci: Realistik, Penelitian Tindakan Kelas, Bilangan Pecahan, Hasil Belajar.
\end{abstract}

\begin{abstract}
Enhancing Students' Learning Outcomes through Realistic Mathematics Approach on Fractions)

This research is motivated by the low learning process and audit of learning outcomes that are not balanced between cognitive, affective and psychomotor in aspects of Cipedak 06 Pagi Public Elementary School, Jagakarsa District, South Jakarta. The subject of the study was conducted in grade $V$ elementary school with the number of students 32. Improvements in the selection of learning models, a model that prioritized students in understanding and applying the concepts they learned, a model that is a model of the application of realistic mathematics. The research method is a Design Activity. The subject of this research is SD Negeri Cipedak 06 Pagi, Jagakarsa District, South Jakarta; implemented 2 cycles of 4 meetings in the even semester of 2017/2018 school year. Activities in the Learning cycle from cycle I to cycle II are reduced and effective. In the first cycle it worked well with the results of the pre-test results increased in the post-test on the first action from $43.75 \%$ to $71.88 \%$ an increase of $28.13 \%$ with an average of 67.81 . Whereas in the second action the results of Pre-Test and Post-Test were $68.75 \%$ to $75 \%$ with an average of 69.97. The results of Cycle II first action in the pre-test and post-test were from $75 \%$ to $81.75 \%$ with an average of 73.06. The results of the pre-test and Post-test from the second action were $84.38 \%$ to $93.75 \%$ with an average of 77.94 .

Keyword: Realistic, Action Research, Fractions, Learning Outcomes.
\end{abstract}




\section{Pendahuluan}

Matematika lebih sering dipandang sebagai sebuah pelajaran yang menakutkan, sulit dan abstrak. Matematika yang dipelajari di sekolah lebih banyak menekankan kepada hafalan. Guru cenderung hanya mentransferkan ilmu dan siswa hanya menerima dengan pasif. Pada dasarnya siswa Sekolah Dasar (SD) Menurut teori perkembangan intelektual Piaget, anak SD berada pada periode operasional konkret. Siswa SD masih terikat dengan objek konkret yang dapat ditangkap oleh panca indra. Dalam pembelajaran matematika yang abstrak, siswa memerlukan alat bantu berupa media, dan alat peraga yang dapat memperjelas apa yang disampaikan oleh guru sehingga lebih cepat dipahami dan dimengerti oleh siswa (Heruman, 2007: 1). Berpikir anak tentang matematika, khususnya pecahan, masih mendasarkan

Berdasarkan permasalahan di atas, penerapan metode pembelajaran yang bervariasi dan inovatif sangat diperlukan dalam pembelajaran matematika. Adapun salah satu caranya adalah dengan Realistik (PMR). Mengingat pada usia anak sekolah dasar, perkembangan berpikir mereka masih dalam tahap konkret.

Realistik Mathematics Education (RME) dalam bahasa Indonesia dikenal dengan Pendekatan Matematika Realistik (PMR) merupakan teori belajar mengajar dalam pendidikan matematika. Teori PMR benda-benda konkret dan situasi nyata. menggunakan Pendekatan Matematika

pertama kali diperkenalkan dan dikembangkan di Belanda pada tahun 1970 oleh Institut Freudenthal. Teori ini mengacu pada pendapat Freudenthal yang mengatakan bahwa matematika harus dikaitkan dengan realita dan matematika merupakan aktivitas manusia. Ini berarti matematika harus dekat dengan anak dan relevan dengan kehidupan nyata seharihari.

Diungkapkan oleh Marpaung (2009: 1) bahwa dengan pendekatan matematika realistik, matematika bukan lagi sebagai mata pelajaran yang menakutkan bagi siswa namun sudah menjadi pelajaran yang menyenangkan karena proses pembelajaran tidak lagi bersifat satu arah. Secara umum dapat dikatakan bahwa pendekatan matematika realistik merupakan pendekatan pembelajaran yang menekankan pada aktifitas siswa, dan dalam pembelajarannya menggunakan konteks dunia nyata.

Penelitian-penelitian relevan telah mengkaji RME dikaitkan dengan beberapa variable lainnya, yaitu: Materi Sifat Komutatif dan Asosiatif (Afriansyah, 2012); Materi Bilangan Desimal (Afriansyah \& Putri, 2014); Kemampuan Komunikasi Matematis (Alamiah \& Afriansyah, 2017); dan Kemampuan Koneksi Matematis (Latipah \& Afriansyah, 2018).

Sehubungan dengan hal-hal tersebut, maka penulis tertarik untuk melakukan penelitian guna meningkatkan hasil belajar Matematika pada materi pecahan. Secara jelas, judul penelitian yaitu "Peningkatan Hasil Belajar Siswa Melalui Pendekatan 
Matematik Realistik dalam Pembelajaran Matematika pada Pokok Bahasan Bilangan Pecahan" (Penelitian Tindakan Kelas Siswa Kelas V di SD Negeri Cipedak 06 Pagi Kecamatan Jagakarsa Jakarta Selatan).

Beberapa penelitian telah meneliti tentang hasil belajar, dikaitkan dengan: Model Pembelajaran Generatif (Madio, 2012); Kooperatif Tipe Think Pair Share (Sari \& Madio, 2013); Motivasi Belajar (Warti, 2016); Model Active Knowledge Sharing (Sari, 2016); Model Pembelajaran Berbasis Masalah (Nst \& Rahmi, 2017); Strategi Pembelajaran Make a Match dan Index Card Match (Anggraini, Jufri, \& Juliati, 2017); Media Pembelajaran Komik (Florayu, Isnaini, \& Testiana, 2017); Problem Based Learning (Julita, 2018); Pengaruh Sikap Ilmiah (Razak \& Kamaruddin, 2018); dan Metode Pembelajaran STAD (Putri \& Sutriyono, 2018).

Dalam pembelajaran matematika di tingkat SD, diharapkan terjadi reinventation (penemuan kembali). Penemuan kembali adalah menemukan suatu cara penyelesaian secara informasi dalam pembelajaran di kelas. Walaupun penemuan itu sederhana dan bukan hal yang baru bagi orang yang mengetahuinya, tetapi bagi siswa SD penemuan tersebut merupakan sesuatu yang baru (Heruman, 2007: 4).

Suatu pendekatan digunakan ketika orang akan mengerjakan sesuatu, dan menetapkan sasaran yang hendak dicapai. Untuk mencapai sasaran tersebut seseorang memilih pendekatan yang tepat Mosharafa: Jurnal Pendidikan Matematika Volume 7, Nomor 3, September 2018 Copyright $\odot 2018$ Mosharafa: Jurnal Pendidikan Matematika sehingga diperoleh hasil yang optimal, berhasil guna dan tepat guna. Adapun pendekatan pembelajaran dimaknai sebagai cara yang ditempuh guru dalam pelaksanaan pembelajaran agar konsep yang disajikan bisa beradaptasi dengan siswa.

Salah satu pembelajaran matematika yang berorientasi pada matematisasi pengalaman sehari-hari (mathematize of everyday experience) dan menerapkan matematika dalam kehidupan sehari-hari adalah Pembelajaran Matematika Realistik (PMR).

Realistik Mathematics Education (RME) dalam bahasa Indonesia dikenal dengan Pendekatan Matematika Realistik (PMR) merupakan teori belajar mengajar dalam pendidikan matematika. Teori ini mengacu pada pendapat Freudenthal yang mengatakan bahwa matematika harus dikaitkan dengan realita dan matematika merupakan aktivitas manusia. Ini berarti matematika harus dekat dengan anak dan relevan dengan kehidupan nyata seharihari. Matematika sebagai aktivitas manusia berarti manusia harus diberikan kesempatan untuk menemukan kembali ide dan konsep matematika dengan bimbingan orang dewasa (Gravemeijer, 1994).

Upaya ini dilakukan melalui penjelajahan berbagai situasi dan persoalan-persoalan "realistik". Realistik dalam hal ini dimaksudkan tidak mengacu pada realitas tetapi pada sesuatu yang dapat dibayangkan oleh siswa (Slettenhaar, 2000). Sehingga makna dari 
http://journal.institutpendidikan.ac.id/index.php/mosharafa

realistic pada RME bukan makna realistic sebenarnya (Afriansyah, 2016a). Prinsip penemuan kembali dapat diinspirasi oleh prosedur-prosedur pemecahan informal, sedangkan proses penemuan kembali menggunakan konsep matematisasi. RME memberikan kesempatan pada peserta didik untuk lebih aktif dalam pembelajaran, dikarenakan pembelajaran yang dilakukan lebih terpusat pada peserta didik. (Afriansyah, 2017)

Pengembangan pembelajaran matematika dengan pendekatan realistik merupakan salah satu usaha meningkatkan kemampuan siswa dalam memahami matematika (Erman Suherman, dkk., 2003: 145). Diungkapkan oleh Marpaung (2009: 1) bahwa dengan pendekatan matematika realistik, matematika bukan lagi sebagai mata pelajaran yang menakutkan bagi siswa namun sudah menjadi pelajaran yang menyenangkan karena proses pembelajaran tidak lagi bersifat satu arah. Mengenai Pendekatan Matematika Realistik. Secara umum dapat dikatakan bahwa pendekatan matematika realistik merupakan pendekatan pembelajaran yang menekankan pada aktifitas siswa, dan dalam pembelajarannya menggunakan konteks dunia nyata. Melalui Pendekatan Matematika Realistik, kemampuan matematis siswa cenderung meningkat. (Afriansyah, 2016b)

Pendekatan realistik adalah suatu pendekatan yang menggunakan masalah realistik sebagai pangkal tolak pembelajaran. Melalui aktivitas matematisasi horisontal dan vertikal diharapkan siswa dapat menemukan dan mengkonstruksi konsep-konsep matematika.

Hasil belajar yang utama adalah pola tingkah laku yang bulat yang diperoleh oleh setiap siswa setelah proses belajar. Di dalam proses belajar siswa mengerjakan hal-hal yang akan dipelajari sesuai dengan tujuan dan maksud belajar. Hasil belajar akan dinyatakan dalam bentuk penguasaan, penggunaan sikap dan nilai, pengetahuan dan kecakapan dasar yang terdapat dalam berbagai bidang studi atau lebih luas lagi dalam berbagai aspek kehidupan atau pengalaman yang terorganisasi. (Tabrani, 1996: 8).

Dari beberapa pendapat tentang hasil belajar di atas maka dapat disimpulkan bahwa hasil belajar adalah hasil yang diperoleh siswa setelah mengalami interaksi proses pembelajaran melalui evaluasi belajar matematika yang dilakukan dengan tes yang dijadwalkan. Kemajuan yang diperoleh siswa tidak hanya berupa ilmu pengetahuan, tetapi juga berupa sikap dan kecakapan atau keterampilan khususnya dalam mata pelajaran matematika.

\section{Metode}

Penelitian ini dilaksanakan di kelas V SD Negeri Cipedak 06 Pagi Kecamatan Jagakarsa Jakarta Selatan. Penelitian ini menekankan kepada penggunaan pendekatan matematik realistik dalam pembelajaran matematika pada pokok

Mosharafa: Jumal Pendidikan Matematika Volume 7, Nomor 3, September 2018 Copyright $\odot 2018$ Mosharafa: Jurnal Pendidikan Matematika 
bahasan pengurangan dan penjumlahan pecahan berpenyebut sama dan tidak sama untuk meningkatkan hasil belajar siswa.

Penelitian Tindakan Kelas ini dilaksanakan di SD Negeri Cipedak 06 Pagi Kecamatan Jagakarsa Jakarta Selatan. Pelaksanaannya dilaksanakan 2 siklus 4 pertemuan pada semester genap tahun ajaran 2017/2018, adapun waktunya sebagai berikut:

1. Siklus ke I dilaksanakan 2 tindakan. Tindakan ke 1 pada hari Selasa, 06 Februari 2018. Pada pukul 07.30-08.40. tindakan ke 2 pada tanggal 13 Februari 2018, pada pukul 07.30-08.40.

2. Siklus ke II dilaksankan pada hari Selasa tanggal 20 Februari 2018, dan tindakan ke 2 pada tanggal 27 Februari 2018, pada pukul 07.30-08.40.

Subjek dalam penelitian ini adalah siswa kelas $\mathrm{V}$ yang muridnya berjumlah 32 siswa tahun ajaran 2017/2018 dengan prestasi dan kemampuan masih rendah. Kegiatan Penelitian Tindakan Kelas ini akan dilakukan dalam Pembelajaran matematika pada semester Genap tahun 2018 pada pokok bahasan bilangan pecahan. Jumlah siswa yang menjadi subjek penelitian sebanyak 32 orang terdiri dari 20 orang siswa laki-laki dan 12 orang siswa perempuan.

Prosedur yang ditempuh dalam penyelesaian penelitian ini terdiri dari beberapa tahap sebagai berikut:

1. Identifikasi masalah,

2. Rumusan masalah,

3. Tahap perencanaan penelitian
4. Pelaksanaan Tindakan

Pengolahan data yang diperoleh dari hasil penelitian ini dilakukan secara kuantitatif dan kualitatif. Adapun data yang diperoleh dan di dapat dari hasil observasi siswa dan guru serta hasil tes siswa pada saat pembelajaran berlangsung menjadi data kuantitatif. Sedangkan untuk data yang menunjukan proses interaksi yang terjadi selama digunakan metode kualitatif. Data yang diperoleh dari lembar aktifitas siswa, observasi guru dan studi dokumentasi tersebut kemudian diolah dan dibuat persentasenya dari hasil pre test dan post test.

Penentuan tingkat keberhasilan belajar siswa berdasarkan skor yang diperoleh dicari dengan menggunakan rumus:

\section{Presentase Kemampuan$$
=\frac{\text { Jumlah skor yang diperolh }}{\text { Skor Total }} \times 100
$$

Untuk mengklasifikasi kualitas pemahaman matematika siswa, maka data hasil tes dikelompokkan dengan menggunakan Skala Lima (Suherman dan Kusumah, 1990: 272), yaitu sebagai berikut

Tabel 1.

Klasifikasi Kualitas Pemahaman Matematika Siswa

\begin{tabular}{cc|}
\hline $\begin{array}{c}\text { Persentase Skor } \\
\text { Total Siswa }\end{array}$ & $\begin{array}{c}\text { Kategori } \\
\text { Kemampuan Siswa }\end{array}$ \\
\hline $90 \%<\mathrm{A} \leq 100 \%$ & $\mathrm{~A}$ (Sangat Baik) \\
\hline $75 \%<\mathrm{B} \leq 90 \%$ & $\mathrm{~B}$ (Baik) \\
\hline $55 \%<\mathrm{C} \leq 75 \%$ & $\mathrm{C}$ (Cukup) \\
\hline $40 \%<\mathrm{D} \leq 55 \%$ & $\mathrm{D}$ (Kurang) \\
\hline $0 \%<\mathrm{E} \leq 40 \%$ & $\mathrm{E}$ (Buruk) \\
\hline
\end{tabular}


Penelitian tindakan kelas ini dianggap berhasil apabila meningkatnya indikator sebagai berikut:

1. Terapan Pendekatan Metode Realistik dapat meningkatkan hasil belajar siswa pada pelajaran matematika dengan pokok bahasan bilangan pecahan. Adanya keseriusan siswa dalam mengerjakan materi, keterlibatan siswa berpartisipasi dalam kelompok dan kecepatan respon siswa terhadap tugas yang diberikan guru.

2. Adanya peningkatan pembelajaran bilangan pecahan pada mata pelajaran matematika mencapai kategori baik yaitu berada pada rentang 66-79.

3. Tingkat pemahaman siswa terhadap penerapan Pendekatan Metode Realistik pada pokok bahasan Bilangan Pecahan pada mata pelajaran matematika dalam tes akhir telah mencapai KKM yang telah ditetapkan yaitu sebesar 60 .

\section{Hasil dan Pembahasan}

Perencanaan pembelajaran menjadi bagian yang cukup penting untuk menciptakan pembelajaran yang kondusif. Untuk itu perencanaan pembelajaran dalam setiap siklus disusun secara sistematis. RPP yang disusun dalam penelitian ini mengacu pada langkahlangkah pendekatan pembelajaran realistik dengan menggunakan permasalah yang nyata sebagai awal permulaan dari pembelajaran. Untuk Indikator dirumuskan berdasarkan Standar Kompetensi dan Kompetensi Dasar yang diambil dari 418
Standar Isi. Materi pada penelitian ini dibatasi pada materi penjumlahan pecahan berpenyebut sama untuk tindakan pertama serta penjumlahan pecahan tidak sama untuk tindakan kedua pada siklus I dan materi pengurangan pecahan berpenyebut sama untuk tindakan pertama dan pengurangan pecahan berpenyebut tidak sama untuk tindakan kedua pada siklus II.

Dalam pelaksanaannya perencanaan pada siklus II dibuat dengan mengacu pada hasil refleksi kegiatan pada siklus I, perubahan lebih terlihat dari persiapan guru dalam mengajar terutama dalam penggunaan media pembelajaran yang lebih variatif dan lebih baik dibanding siklus I pada siklus II. Perubahan juga dilakukan dalam RPP dengan merubah posisi tempat duduk dan anggota kelompok belajar sehingga memudahkan siswa dalam bekerjasama.

Perubahan dalam perencanaan dari siklus I pada tindakan pertama dan tindakan kedua ke siklus dua tindakan pertama dan kedua dilakukan berdasarkan hasil observasi dan refleksi yang peneliti lakukan sehingga hasil belajar matematika siswa bisa meningkat setiap siklus dan tindakan berikutnya.

Guru dalam proses pembelajaran pada dasarnya sudah melaksanakan pembelajaran mengikuti langkah-langkah yang sesuai dengan prinsip pendekatan realistik. Namun dalam pelaksanaannya masih terdapat kekurangan yang dialami oleh peneliti. Banyak siswa yang kesulitan memahami permasalahan yang diberikan 
oleh guru diawal pembelajaran hal ini dikarenakan siswa belum terbiasa dengan pembelajaran matematika dengan pendekatan realistik. Selain itu penggunaan media harus dipersiapkan lebih baik untuk mempermudah dan mendukung pembelajaran. Penataan kelompok dan posisi tempat duduk yang tidak efektif pada siklus I tindakan pertama membuat peneliti harus merubah pada tindakan kedua dan siklus II baik tindakan pertama dan kedua. Siswa juga diberi motivasi untuk mengikuti pembelajaran dengan semangat dalam menyelesaikan permasalahan dengan cara mereka sendiri serta bekerjasama dengan baik dalam kegiatan kelompok.

Hasilnya pada tindakan siklus II aktivitas guru dan siswa mulai berubah. Pembelajaran berlangsung lebih baik, guru melakukan penyampaian materi lebih baik terutama dalam mengajukan dan membahas contoh permasalahan. Siswa mulai terbiasa dengan belajar secara berkelompok dan juga lebih mudah untuk diatur ketika belajar kedalam kelompok. Dengan motivasi yang diberikan guru, siswa lebih aktif dibanding siklus pertama. Selain itu dengan inivosai media dan LKS yang membuat siswa lebih termotivasi untuk bekerja sama dan diskusi. Siswa juga lebih aktif dalam melakukan tanya jawab dengan guru dalam proses pembelajaran. Selain itu pemahaman dan hasil belajar tentang konsep materi yang diberikan semakin meningkat ini berarti bahwa tingkat hasil belajar siswa bisa meningkat

Mosharafa: Jurnal Pendidikan Matematika

Volume 7, Nomor 3, September 2018

Copyright @ 2018 Mosharafa: Jurnal Pendidikan Matematika dengan menggunakan pendekatan matematika realistik.

Pembahasan gambaran mengenai pelaksanaan dan aktivitas guru dan siswa dalam penelitian ini bisa dilihat dari hasil observasi yang telah dilakukan oleh observer. Dari hasil observasi tersebut dapat dilihat secara keseluruhan proses pembelajaran baik aktivitas guru maupun siswa selama pembelajaran dengan menggunakan pendekatan matematika realistik. Peningkatan ini ternyata berpengaruh terhadap hasil belajar siswa yang diperoleh dari hasil post-test setiap tindakan baik siklus I maupun siklus II.

Untuk melihat peningkatan hasil belajar matematika pokok bahasan penjumlahan dan pengurangan pecahan berpenyebut sama dan tidak sama siswa kelas V SD Negeri Cipedak 06 Pagi Kecamatan Jagakarsa Jakarta Selatan pada penelitian ini, peneliti membandingkan hasil tes pretest siswa sebelum dengan hasil tes akhir post-test sesudah dilaksanakannya pembelajaran dengan menggunakan pendekatan realistik matematika pada setiap tindakan baik siklus I maupun siklus II. Peningkatan hasil belajar dapat dilihat dari perubahan skor dan rata-rata skor yang diperoleh oleh siswa.

Dari data hasil pre-test siklus I tindakan 1, 14 siswa atau 43,75\% siswa dinyatakan lulus dalam pre-test dan sisanya 18 siswa atau $56,25 \%$ siswa dinyatakan belum lulus dalam pre-test. Setelah pembelajaran dilaksanakan, pada tahap kerja individual dilaksanakan post-test yaitu untuk mengukur keberhasilan pembelajaran 
yang telah dilaksanakan dengan menerapkan pendekatan matematika realistik sesuai dengan tujuan pembelajaran yang telah dirumuskan pada rencana pelaksanaan pembelajaran. Data dari siklus I tindakan 1 menunjukan bahwa sebanyak 23 siswa atau 71,88 \% dinyatakan lulus dan 9 siswa atau 28,13\% dinyatakan belum lulus dalam post-tes Dengan rata-rata sebesar 67,81. Ketuntasan belajar meningkat sebesar $28,13 \%$.

Sedangkan pada hasil pre-test siklus I tindakan kedua 22 siswa atau 68,75 \% siswa dinyatakan lulus dalam pre-test dan sisanya 10 siswa atau 31,25 \% siswa dinyatakan belum lulus dalam pre-test. Rata-rata kelas yang diperoleh dari hasil pre-test adalah 63,84. Setelah pembelajaran dilaksanakan, pada tahap kerja individual dilaksanakan post-test yaitu untuk mengukur keberhasilan pembelajaran yang telah dilaksanakan dengan menerapkan pendekatan matematika realistik sesuai dengan tujuan pembelajaran yang telah dirumuskan pada rencana pelaksanaan pembelajaran. Adapun hasil post-test pada siklus I tindakan kedua menunjukan bahwa sebanyak 24 siswa atau 75 \% dinyatakan lulus dan 8 siswa atau 25\% dinyatakan belum lulus dalam post-tes dengan ratarata 69,97 . Ketuntasan belajar meningkat sebesar $6,25 \%$.

Pada siklus II tindakan pertama data hasil pre-test menunjukan 24 siswa atau
75\% siswa dinyatakan lulus dalam pre-test dan sisanya 8 siswa atau 25\% siswa dinyatakan belum lulus dalam pre-test. Setelah pembelajaran dilaksanakan posttest yaitu untuk mengukur keberhasilan pembelajaran yang telah dilaksanakan dengan menerapkan pendekatan matematika realistik. Adapun hasil posttest dari siklus II tindakan kesatu sebanyak 26 siswa atau 81,25\% dinyatakan lulus dan 6 siswa atau 18,75 \% dinyatakan belum lulus dalam post-tes dengan rata-rata 73,06. Ketuntasan belajar meningkat sebesar 6,25\%.

Dari data hasil pre-test siklus II tindakan kedua 27 siswa atau 84,38\% siswa dinyatakan lulus dalam pre-test dan sisanya 5 siswa atau 15,63\% siswa dinyatakan belum lulus dalam pre-test. Setelah pembelajaran dilaksanakan posttest yaitu untuk mengukur keberhasilan pembelajaran yang telah dilaksanakan dengan menerapkan pendekatan matematika realistik. Selama pembelajaran dengan menerapkan pendekatan matematika realistik ini, hasil yang cukup menggembirakan terlihat dari peningkatan yang muncul pada hasil posttest yang diberikan. sebanyak 30 siswa atau 93,75\% dinyatakan lulus dan 2 siswa atau $6,25 \%$ dinyatakan belum lulus dalam post-tes dengan rata-rata 77,94. Ketuntasan belajar meningkat sebesar $9,38 \%$. 


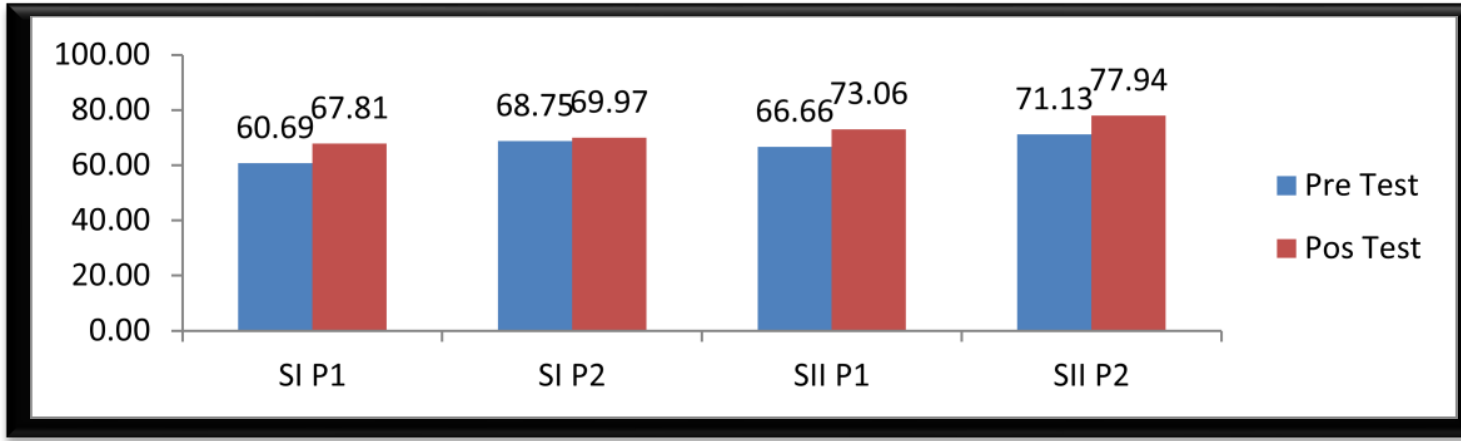

Gambar 1. Hasil Pretest dan Posttest.

Aktivitas guru dan siswa berpengaruh terhadap hasil yang dicapai siswa sehingga dapat dikatakan bahwa penerapan Pendekatan Matematika Realistik selain dapat meningkatkan aktivitas guru dan siswa juga dapat meningkatkan hasil belajar siswa. Selain itu, pelaksanaan pembelajaran lebih berpusat kepada siswa sehingga guru hanya memberikan bimbingan dan memfasilitasi kegiatan siswa untuk belajar. Dari gambar 2 dapat dilihat ketuntasan belajar dari siklus ke siklus, dapat diambil kesimpulan bahwa Pendekatan Matematika Realistik dapat meningkatkan hasil belajar siswa pada materi pokok penjumlahan dan pengurangan pecahan berpenyebut sama dan tidak sama mata pelajaran matematika.

Dalam penelitian ini, peneliti menilai hasil tes pre-test siswa sebelum dengan hasil tes akhir post-test sesudah dilaksanakannya pembelajaran dengan menggunakan pendekatan realistik matematika. Peningkatan hasil belajar dapat dilihat dari perubahan skor dan ratarata skor yang diperoleh oleh siswa. Terlihat adanya peningkatan dari setiap siklus, berikut gambar peningkatan hasil belajar setiap tindakan baik siklus I maupun siklus II.

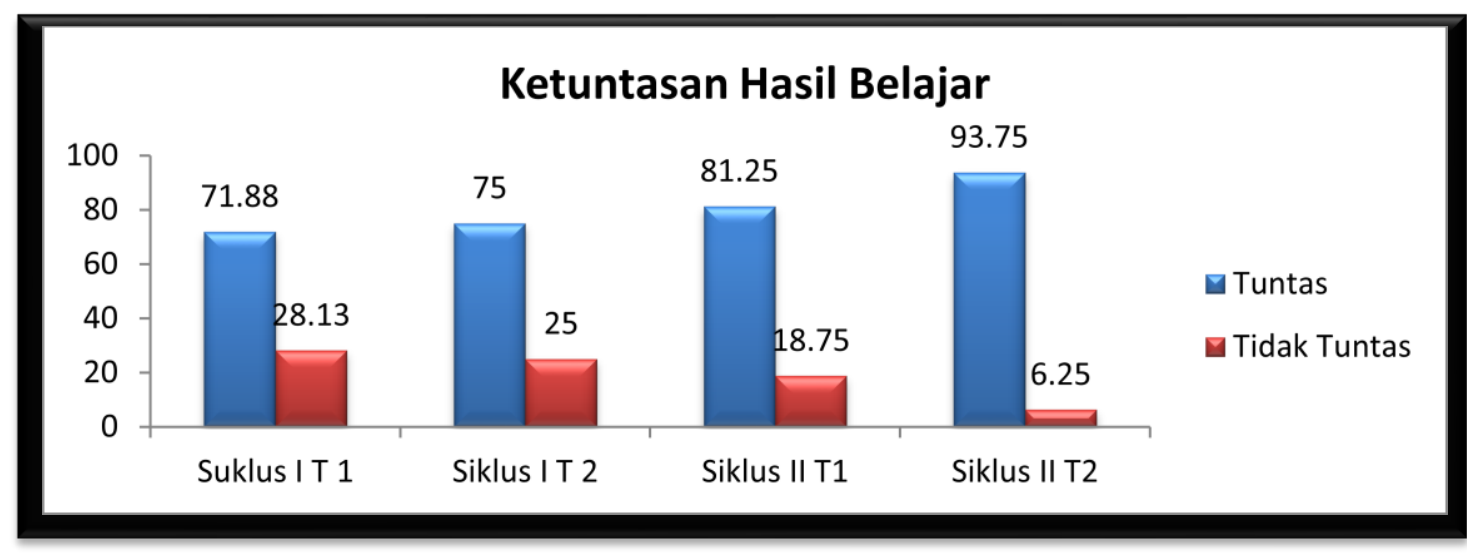

Gambar 2. Ketuntasan Hasil Belajar Tiap Siklus

\section{Mosharafa: Jurnal Pendidikan Matematika}




\section{Penutup}

Berdasarkan penelitian yang dilakukan, maka beberapa kesimpulan yang dapat diperoleh adalah sebagai berikut: 1) Perencanaan pembelajaran dengan menggunakan pendekatan matematika realistik, dibuat oleh penulis dengan sebaik mungkin dengan mengacu kepada KTSP disertai dengan penggunaan media pembelajaran, lembar observasi guru dan siswa, lembar kerja siswa, dan tes evaluasi di akhir setiap siklus. Pada pembelajaran menggunakan pendekatan matematik realistik memiliki kelebihan yaitu guru mengawali pembelajaran matematika dengan mengajukan permasalahan dan menggunakan media yang berkaitan dengan kehidupan sehari-hari untuk membangun pengetahuan matematika siswa serta kegiatan pembelajaran matematik realistik lebih menekankan kepada aktifitas siswa bukan aktifitas guru, tampak pada aktifitas siswa dalam kegiatan diskusi, tanya jawab dan memberikan tanggapan; 2) Pelaksanaan pembelajaran melalui pendekatan realistik pada pokok bahasan bilangan pecahan dilaksanakan sesuai rencana yang telah dipersiapkan. Berdasarkan hasil observasi pada Siklus I tindakan pertama dan kedua guru sudah melaksanakan pembelajaran sebaik mungkin dengan mengacu pada tahapan pendekatan matematik realistik. Pada siklus I baik tindakan pertama maupun kedua peneliti masih mengalami banyak kendala selama proses pembelajaran sehingga masih banyak yang

harus ditingkatkan sedangkan pada pada siklus II baik tindakan pertama dan tindakan kedua guru sudah lebih meningkatkan seiring dengan perbaikan pembelajaran melalu refleksi yang telah dilakukan dalam pengelolaan kelas dan penggunaan media pembelajaran yang lebih baik. Selain itu pada siklus I tindakan pertama maupun tindakan kedua banyak siswa yang belum memahami sehingga hasil belajar siswa masih kurang dan terjadi penurunan hasil belajar maka pada siklus II baik tindakan pertama maupun kedua mengalami peningkatan secara klasikal maupun individu pada siklus ke II; dan 3) Peningkatan hasil belajar dengan menggunakan pendekatan matematik realistik berhasil cukup baik. Dari perbaikan pembelajaran yang dilakaukan berdasarkan hasil refleksi pada siklus I berhasil dengan baik ditandai dengan adanya peningkatan hasil tes dari hasil pretest meningkat dalam post-test pada tindakan pertama dari 43,75\%menjadi $71,88 \%$ terjadi peningkatan sebanyak $28,13 \%$ dengan rata-rata sebesar 67,81. Sedangkan dalam tindakan kedua hasil Pre-Test dan Post-Test adalah 68,75\% menjadi 75\% dengan rata-rata 69,97. Hasil dari Siklus II tindakan pertama dalam pretest dan post-test adalah dari $75 \%$ menjadi $81,75 \%$ dengan rata-rata 73,06 . Hasil pre-test dan Post-test dari tindakan kedua adalah 84,38\% menjadi 93,75\% dengan rata-rat 77,94. Hasil pembelajaran pada saat pre-test dan post-test mengalami kenaikan dari tiap siklusnya. 
Dan hasil yang paling signifikan dapat dilaihat dari siklus II pada tindakan kedua.

\section{Daftar PUstaka}

Afriansyah, E. A. (2012). Implementasi PMRI dalam Materi Sifat Komutatif dan Asosiatif pada Bilangan Bulat untuk Level Siswa SD/MI. Mosharafa: Jurnal Pendidikan Matematika, 1(2), 67-72.

Afriansyah, E. A., \& Putri, R. I. I. (2014). Design Research: Konsep Nilai Tempat Pada Operasi Penjumlahan Bilangan Desimal Di Kelas V Sekolah Dasar. Jurnal Pendidikan Matematika UNSRI, 8(1), 13-24. Retrieved from http://ejournal.unsri.ac.id/index.php/ jpm/article/view/1857/761

Afriansyah, E. A. (2016a). Makna Realistic dalam RME dan PMRI. LEMMA, II(2), 96-104.

https://doi.org/10.22202/jl.2016.v2i2. 578

Afriansyah, E. A. (2016b). Investigasi Kemampuan Problem Solving dan Problem Posing Matematis Mahasiswa via Pendekatan Realistic. Mosharafa: Jurnal Pendidikan Matematika, 5(3), 269-280.

Afriansyah, E. A. (2017). Desain Lintasan Pembelajaran Pecahan melalui Pendekatan Realistic Mathematics Education. Mosharafa: Jurnal Pendidikan Matematika, 6(3), 463474.

Alamiah, U. S., \& Afriansyah, E. A. (2017). Perbandingan Kemampuan Komunikasi Matematis Siswa antara yang Mendapatkan Model Pembelajaran Problem Based
Learning dengan Pendekatan Realistic Mathematics Education dan OpenEnded. Mosharafa: Jurnal Pendidikan Matematika, 6(2), 207-216.

Anggraini, V., Jufri, L. H., dan Juliati, W. (2017). Peningkatan Hasil Belajar Matematika Siswa Menggunakan Strategi Pembelajaran Make a Match dan Index Card Match pada Siswa Kelas VIII SMPN 1 Koto XI Tarusan Tahun Pelajaran 2016/2017. Mosharafa: Jurnal Pendidikan Matematika, 6(2), 201-206.

Florayu, B., Isnaini, M., dan Testiana, G. (2017). Pengaruh Penggunaan Media Pembelajaran Komik terhadap Peningkatan Hasil Belajar Matematika Siswa Kelas VII di Sekolah Menengah Pertama Negeri 10 Palembang. Mosharafa: Jurnal Pendidikan Matematika, 6(1), 45-51.

Gravemeijer, K. (1994) Developing Realistic Mathematics Education. Utrech: Kluwer Academic Publisher.

Heruman, (2007). Model Pembelajaran Matematika. Bandung: Remaja Rosdakarya Offset.

Julita. (2018). Peningkatan Kemampuan Pemecahan dan Hasil Belajar Matematika melalui Problem BasedLearning. Mosharafa: Jurnal Pendidikan Matematika, 7(1), 143154.

Kaunang, D. F. (2018). Penerapan Pendekatan Realistic Mathematics Education dalam Pembelajaran Matematika Materi Persamaan Garis Lurus di SMP Kristen Tomohon. 
http://journal.institutpendidikan.ac.id/index.php/mosharafa

Mosharafa: Jurnal Pendidikan

Matematika, 7(2), 307-314.

Latipah, E. D. P., \& Afriansyah, E. A. (2018). Analisis Kemampuan Koneksi Matematis Siswa Menggunakan Pendekatan Pembelajaran CTL dan RME. Jurnal Matematika, 17(1), 1-12. Retrieved from https://ejournal.unisba.ac.id/index.ph $\mathrm{p} /$ matematika/article/view/3691/237 0

Madio, S. S. (2012). Model Pembelajaran Generatif dalam Upaya Meningkatkan Hasil Belajar Matematika. Mosharafa: Jurnal Pendidikan Matematika, 1(1), 29-34.

Marpaung, Y. dan Julie, H. (2009). PMRI dan PISA: Suatu Usaha Peningkatan Mutu Pendidikan Matematika di Indonesia. Retrieved from: http://p4mriusd.blogspot.com/

Nst, M. N. dan Rahmi, R. (2017). Pengaruh Penerapan Model Pembelajaran Berbasis Masalah disertai Teknik Berikan Uangnya terhadap Hasil Belajar Matematika Siswa Kelas VIII SMPN 16 Padang. Mosharafa: Jurnal Pendidikan Matematika, 6(2), 273278.

Putri, K. C. dan Sutriyono. (2018). Pengaruh Metode Pembelajaran STAD terhadap Hasil Belajar Matematika pada Siswa Kelas VIII. Mosharafa: Jurnal Pendidikan Matematika, 7(2), 295-306.

Razak, F. dan Kamaruddin, R. (2018). Pengaruh Sikap IImiah Siswa terhadap Hasil Belajar Materi Bangun Ruang Siswa Kelas VIII SMP Negeri 3
Minasatene. Mosharafa: Jurnal Pendidikan Matematika, 7(1), 133142.

Rusyan, T. dkk. (1996). Pendekatan Dalam Proses Belajar Mengajar. Bandung. Remaja Rosdakarya.

Sari, S. P. dan Madio, S. S. (2013). Pengaruh Penerapan Model Pembelajaran Kooperatif Tipe Think Pair Share (TPS) terhadap Hasil Belajar Matematika Siswa SMP. Mosharafa: Jurnal Pendidikan Matematika, 2(1), 37-54.

Sari, E. F. P. (2016). Penerapan Model Active Knowledge Sharing dalam Pembelajaran Matematika Siswa Kelas VII di SMPN 18 Palembang. Mosharafa: Jurnal Pendidikan Matematika, 5(3), 335-342.

Slettenhaar. (2000). Adapting Realistic Mathematics Education in the Indonesian Context. Dalam Majalah Ilmiah Himpunan Matematika Indonesia. Bandung: Prosiding Konperensi Nasional Matematika X ITB, 17-20 Juli 2000.

Suherman dan Kusumah. (1990). Petunjuk Praktis untuk Melaksanakan Evaluasi Pendidikan Matematika. Bandung: Wijayakusumah.

Warti, E. (2016). Pengaruh Motivasi Belajar Siswa terhadap Hasil Belajar Matematika Siswa di SD Angkasa 10 Halim Perdana Kusuma Jakarta Timur. Mosharafa: Jurnal Pendidikan Matematika, 5(2), 177-185. 